\title{
Functional roles of neurotransmitters and neuromodulators in the dorsal striatum
}

\author{
Jeehaeh Do, ${ }^{1}$ Jae-Ick Kim, ${ }^{2}$ Joseph Bakes, ${ }^{1}$ Kyungmin Lee, ${ }^{3}$ and Bong-Kiun Kaang ${ }^{1,2,4}$ \\ ${ }^{1}$ Department of Brain and Cognitive Sciences, College of Natural Sciences, Seoul National University, Seoul 151-747, Korea; \\ ${ }^{2}$ National Creative Research Initiative Center for Memory, Department of Biological Sciences, College of Natural Sciences, Seoul, \\ National University, Seoul 151-747, Korea; ${ }^{3}$ Department of Anatomy, School of Medicine, Kyungpook National University, \\ 2-101 Dongin-Dong, Daegu 700-842, Korea
}

\begin{abstract}
The dorsal striatum, with its functional microcircuits galore, serves as the primary gateway of the basal ganglia and is known to play a key role in implicit learning. Initially, excitatory inputs from the cortex and thalamus arrive on the direct and indirect pathways, where the precise flow of information is then regulated by local GABAergic interneurons. The balance of excitatory and inhibitory transmission in the dorsal striatum is modulated by neuromodulators such as dopamine and acetylcholine. Under pathophysiological states in the dorsal striatum, an alteration in excitatory and inhibitory transmission may underlie dysfunctional motor control. Here, we review the cellular connections and modulation of striatal microcircuits and propose that modulating the excitatory and inhibitory balance in synaptic transmission of the dorsal striatum is important for regulating locomotion.
\end{abstract}

The dorsal striatum is best known for its role in decision-making, especially in action selection and initiation through the convergence of sensorimotor, cognitive, and motivational information (DeLong 1990; Smith et al. 1998; Balleine et al. 2007). As the primary input of the basal ganglia, the striatum receives glutamatergic inputs from the cortex and thalamus and in turn projects GABAergic outputs to the globus pallidus and substantia nigra pars reticulata $(\mathrm{SNr})$. Inputs from the cortex and thalamus both form excitatory synaptic connections on medium spiny neurons (MSN) in which cortical afferents are from the sensory, motor, and associational cortex (Bolam et al. 2000), and thalamic afferents are from the intralaminar thalamic nuclei (Doig et al. 2010). These glutamatergic inputs are then processed in the dorsal striatum where numerous connections between various types of neurons exist. Thus, the complexity of neuronal circuits has made it difficult to elucidate the functional roles of the striatum. Recently, studies focused on interneurons that reside in the dorsal striatum have characterized the physiological features and functional connections. For example, parvalbumin-expressing fastspiking interneurons (PV-FSI) and neuropeptide-Y positive lowthreshold spiking interneurons (NPY-LTS) form synaptic connections with MSNs and regulate the firing activity of the principal neuron MSNs (Koos and Tepper 1999; Gittis et al. 2010; Chuhma et al. 2011). These interneurons were shown to have distinct firing patterns and connections, and thus they may exert different effects on MSNs. Other crucial connections are the cholinergic, dopaminergic, and serotonergic axons that strongly innervate the dorsal striatum. These projections are essential for modulating striatal circuits and disruption of such signaling can result in movement impairments and neurological disorders such as Huntington's disease (Lovinger 2010). This review summarizes recent reports of the microcircuits present in the dorsal striatum, although serotonergic signaling is excluded, and suggests a putative role for striatal microcircuits in motor dysfunction and/or hyperactivity that often accompany psychiatric disorders

\section{${ }^{4}$ Corresponding author}

Article is online at http://www.learnmem.org/cgi/doi/10.1101/Im.025015.111. Freely available online through the Learning \& Memory Open Access option. such as attention deficit/hyperactivity disorder (ADHD) and autism.

\section{Circuits: Glutamatergic and GABAergic transmission}

\section{Corticostriatal circuit: Direct/indirect pathway}

MSNs constitute $>90 \%$ of the dense GABAergic striatal neuron population and can be subdivided into two main classes: the direct-pathway (striatonigral) and indirect-pathway (striatopallidal) MSNs. The striatonigral MSNs $\left(\mathrm{D}_{1}\right.$-MSN) express high levels of both $\mathrm{D}_{1}$ dopamine (DA) receptors and M4 muscarinic receptors and project directly to the internal globus pallidus (GPi in primates, GPm in rodents) and SNr. Striatopallidal MSNs $\left(\mathrm{D}_{2}-\mathrm{MSN}\right)$ highly express $\mathrm{D}_{2}$ dopamine receptors and adenosine $\mathrm{A}_{2 \mathrm{~A}}$ receptors and project to the external globus pallidus (GPe in primates, GP in rodents). Direct and indirect pathways act in opposition to one another to control movement, which indicates segregated information processing (Albin et al. 1989; DeLong 1990). Compelling evidence of this segregation has been obtained from studies in bacterial artificial chromosome (BAC) transgenic mice (Gong et al. 2003). The existence of synaptic connections between direct- and indirect-pathway MSNs was reported only recently. However, the functional significance of these connections is yet to be characterized.

Cell-type specific whole-cell voltage clamp recordings have revealed distinct physiological properties in $\mathrm{D}_{1}$ - and $\mathrm{D}_{2}$-MSNs in BAC transgenic mice. $D_{2}$-MSNs have a higher NMDA/AMPA (2amino-3-hydroxy-5-methyl-4-isoxazol propionic acid/N-Methyl$\mathrm{D}$-aspartate) ratio. Also, a greater paired-pulse ratio (PPR) value than that of $\mathrm{D}_{1}$-MSN indicates that corticostriatal inputs to $\mathrm{D}_{2}$-MSNs have a higher probability in neurotransmitter release (Ding et al. 2008). Further, membranes of $\mathrm{D}_{2}$-MSNs are intrinsically more excitable than those of $\mathrm{D}_{1}$-MSNs (Kreitzer and Malenka 2007), which is supported by an anatomical comparison of somatodendritic trees, where the surface area of $\mathrm{D}_{1}$-MSNs is larger than that of $\mathrm{D}_{2}$-MSNs (Gertler et al. 2008).

Once the striatonigral direct-pathway circuit receives glutamatergic inputs from the sensorimotor cortex, GABAergic 
$\mathrm{D}_{1}$-MSNs, which project directly to GABAergic neurons in the GPi and $\mathrm{SNr}$, are activated. Thus, GABAergic GPi and SNr neurons, which in turn send axons to motor nuclei of the thalamus, become inhibited. The net effect of this information flow is a disinhibition of excitatory thalamocortical projections. Since the GPi is involved in axial and limb movements and the $\mathrm{SNr}$ in head and eye movements, activation of the striatonigral pathway is predicted to promote action selection and movement. The striatopallidal indirect-pathway circuit also receives glutamatergic inputs from the cortex. Glutamatergic input onto GABAergic $D_{2}$-MSNs inhibits GABAergic pallidal neurons of the GPe, whereupon the target of the GPe neurons, the glutamatergic neurons of the subthalamic nucleus (STN), are disinhibited. Disinhibition of excitatory STN neurons could activate inhibitory output neurons of the GPi and $\mathrm{SNr}$, resulting in a net effect of an inhibition of excitatory thalamocortical projection neurons. This would then lead to a reduction of cortical premotor drive and inhibition of movement.

A compelling number of studies of synaptic plasticity in corticostriatal synapses have been reported, but an in-depth examination of these studies is beyond the scope of this review. Long-term depression (LTD), long-term potentiation (LTP), and spike-timing dependent plasticity (STDP) occur in these types of synapses (Calabresi et al. 1992a,b; Centonze et al. 2001; Fino et al. 2005; Wang et al. 2006; Pawlak and Kerr 2008). Endocannabinoid-dependent LTD (Gerdeman et al. 2002) is much better characterized than NMDAR-dependent or NMDAR-independent LTP because it occurs more frequently than LTP under conditions of high-frequency stimulation (HFS) and depolarization pairing protocol. Whether the properties of synaptic plasticity differ between direct and indirect pathways is unclear.

\section{Thalamostriatal circuit}

The existence of profuse striatal projections from the entire intralaminar nuclear complex was first characterized in a cell degeneration study conducted in primates (Cowan and Powell 1956). Yet, properties of the thalamostriatal projection were much less well understood than those of the corticostriatal circuit. However, a recent approach designed to preserve thalamostriatal axons in brain slices cut in oblique horizontal planes has enabled studies to distinguish physiological properties of thalamostriatal and corticostriatal projections (Smeal et al. 2007). The study in rat oblique horizontal slices proposed dissimilar physiological properties in presynaptic release probability; PPRs of thalamostriatal connections were higher than those of corticostriatal connections. However, another study in mice reported an opposing result, i.e., the PPR in corticostriatal synapses was higher than that in thalamostriatal synapses (Ding et al. 2008, 2010). In addition, the NMDA/AMPA ratio in corticostriatal synapses was higher than that in thalamostriatal synapses, but no distinguishing feature existed between synapses formed between thalamostriatal axons and $\mathrm{D}_{1}$ - or $\mathrm{D}_{2}$-MSNs. A recent study did show that the number of synapses formed along $\mathrm{D}_{1}$-MSNs from the thalamus is regulated by an interaction between Semaphorin 3E (Sema3E) secreted from thalamostriatal axons and Plexin-D1 receptors expressed on $\mathrm{D}_{1}$-MSNs (Ding et al. 2012).

Selective ablation of thalamostriatal axons originating from the parafascicular thalamic nuclei revealed that thalamostriatal axons were not significantly involved in motor-skill learning and spontaneous activity in mice (Kato et al. 2011). Compared with corticostriatal projections, thalamostriatal projections were shown to form fewer synapses on MSNs, but these synapses significantly influenced local striatal circuits by glutamatergic transmission on cholinergic interneurons (Ding et al. 2010).

\section{Local GABAergic circuits: Parvalbumin-expressing fast-spiking interneurons and neuropeptide-Y positive low-threshold spiking interneurons}

The GABAergic interneurons in the striatum form feed-forward inhibitory synaptic connections on both MSNs and neighboring interneurons (Ding et al. 2010). The neighboring interneurons have been largely classified into two groups: parvalbumin positive fast-spiking interneurons (PV-FSI) and neuropeptide-Y expressing low-threshold spiking interneurons (NPY-LTS). Although interneurons constitute a very small population of the dorsal striatum compared to that of MSNs, the minority exerts powerful inhibitory effects on MSNs through GABAergic transmission. Studies have shown that FSIs form multiple synapses, roughly ranging from 135 to 541 in number, on MSNs. One FSI could delay the generation of action potentials in MSNs by a single inhibitory postsynaptic current (IPSC) (Koos and Tepper 1999). FSIs both receive and respond to cortical input faster than MSNs (Kawaguchi 1993), and in turn can exert fast inhibitory actions on both types of MSNs (Planert et al. 2010). BAC transgenic mice in which GABAergic interneurons can be identified showed that FSIs preferentially target direct-pathway MSNs over indirect-pathway MSNs (Gittis et al. 2010). In addition, it is important to note that there is a prominent distinction between the actions of $\mathrm{GABA}_{\mathrm{A}}$ receptors in direct- and indirect-pathway MSNs; currents through $\mathrm{GABA}_{\mathrm{A}}$ receptors always depressed the response to corticostriatal stimulation in $\mathrm{D}_{2}$-MSNs, whereas they helped to depolarize the response in $\mathrm{D}_{1}$-MSNs (Flores-Barrera et al. 2010). Thus the differing nature of synaptic response in each type of MSN may reflect distinct FSI synaptic connectivity; however, a thorough observation needs to be done.

LTS interneurons, which express NPY, somatostatin (SOM), and nitric oxide synthase (NOS) (Galarraga et al. 2007), are much less characterized than FSIs because of their sparse connection to MSNs, cholinergic interneurons, and FSIs (Kawaguchi 1993; Gittis et al. 2010). Although SOM-positive GABAergic terminals have been observed on the dendrites of MSNs (Kubota and Kawaguchi 2000), it has been difficult to explain their functional role. Interestingly, under dopamine depletion states, GABAergic inhibition onto MSNs by LTS interneurons was shown to become potentiated (Dehorter et al. 2009). This distinct set of neurons is thought to modulate striatal circuits by releasing neuromodulators such as NPY, SOM, and NO in a spatial and temporal manner rather than as a fast synaptic transmission (O'Donnell and Grace 1997; West and Grace 2004; Galarraga et al. 2007). For example, one study reported that $\mathrm{D}_{1}$ receptor signaling in the dorsal striatum was upregulated in mice deficient of nitric oxide synthase, and this was accompanied with abnormal social behavior and hyperactivity (Tanda et al. 2009).

GABAergic interneurons in the dorsal striatum are seemingly crucial for facilitating fine movement, as GABAergic dysfunction in the striatum has been linked with hyperkinetic movements like dystonia, tics, and chorea (Levy and Hallett 2002). In experiments where the GABAergic network was interfered, $\mathrm{GABA}_{\mathrm{A}}$ antagonists elicited tic-like movement and other types of dyskinesia (McCairn et al. 2009; Worbe et al. 2009). A more recent study reported that the selective pharmacological inhibition of FSIs leads to robust dystonia-like impairments (Gittis et al. 2011b). Also, previous studies have shown that a state of dopamine depletion induces a rapid shift of FSI connectivity within the striatum (Salin et al. 2009) by increasing synaptic connections with indirect-pathway MSNs (Gittis et al. 2011a). This may result in synchronous firing of indirect-pathway MSNs that could resemble a pathological network oscillation observed in patients of Parkinson's disease (Vida et al. 2006; Assisi et al. 2007; Atallah and Scanziani 2009). 


\section{Neuromodulators: Dopamine and acetylcholine (ACh)}

\section{Modulation of the corticostriatal pathway by dopamine}

Dense innervation of mesencephalic dopaminergic axons modulates the excitability of striatal MSNs, GABAergic interneurons, and cholinergic interneurons. The modulatory action of dopamine differs depending on the cell types because each cell type expresses distinct types of dopamine receptor classes in different combinations. Dopamine receptors are classified into two groups: the $\mathrm{D}_{1}$-like and $\mathrm{D}_{2}$-like receptors. $\mathrm{D}_{1}$-like receptors consist of $\mathrm{D}_{1}$ and $\mathrm{D}_{5}$ receptors, and $\mathrm{D}_{2}$-like receptors consist of $\mathrm{D}_{2}, \mathrm{D}_{3}$, and $\mathrm{D}_{4}$ receptors. Dopamine receptors are G-protein coupled receptors that act through G-proteins, which modulate ion channels and therefore alter the intrinsic property of the cell membrane. $\mathrm{D}_{1}$ and $D_{5}$ receptors activate stimulatory $G_{s / \text { olf }}$ proteins, while $D_{2}$, $D_{3}$, and $D_{4}$ stimulate inhibitory $G_{i / o}$ proteins (Okada et al. 1990; Neve et al. 2004). $G_{s}$ and $G_{\text {olf }}$ proteins in turn stimulate adenylyl cyclase, which elevates the intracellular level of the secondary messenger cAMP, thus activating PKA and its broad range of cellular targets, such as transcription factors and voltage-gated ion channels. On the other hand, $G_{o}$ and $G_{i}$ proteins inhibit adenylyl cyclase (Stoof and Kebabian 1984) and target voltagedependent ion channels, for example through a membranedelimited G-protein mechanism.

Dopamine's effect on principal MSNs has received significant attention because of the distinctive pool of dopamine receptor expression on MSN membranes. In $\mathrm{D}_{1}$-MSNs, $\mathrm{D}_{1}$ receptors act through $\mathrm{G}_{\mathrm{s}}$ and $\mathrm{G}_{\mathrm{olf}}$, and therefore dopamine triggers activation of PKA due to an enhanced level of cAMP. PKA has been shown to increase L-type $\mathrm{Ca}^{2+}$ channel currents (Gao et al. 1997; Hernandez-Lopez et al. 1997) and decrease somatic $\mathrm{K}^{+}$currents (Kitai and Surmeier 1993). Furthermore, activation of the $\mathrm{D}_{1}$ receptor reduces $\mathrm{GABA}_{\mathrm{A}}$ receptor currents through a PKA/ DARPP-32/PP1 signaling cascade (Flores-Hernandez et al. 2000), and $\mathrm{D}_{1}$ receptor signaling inhibits the opening of the $\mathrm{Ca}_{\mathrm{v}} 2 \mathrm{Ca}^{2+}$ channels that activate $\mathrm{Ca}^{2+}$-dependent small conductance $\mathrm{K}^{+}$ channels (Vilchis et al. 2000). Overall, the dopamine modulation on direct-pathway MSNs serves to increase spiking and somatic depolarization.

$\mathrm{D}_{2}$ receptor signaling, which is dominant in indirect pathways, reduces $\mathrm{Na}_{\mathrm{v}} 1$ and $\mathrm{Ca}_{\mathrm{v}} 1 \mathrm{~L}$-type channel currents, but increases outward hyperpolarizing $\mathrm{K}^{+}$channel currents (Greif et al. 1995; Schiffmann et al. 1998; Hernandez-Lopez et al. 2000). Moreover, $\mathrm{D}_{2}$ receptor activation decreases dendritic $\mathrm{Ca}^{2+}$ currents through voltage-dependent channels (Higley and Sabatini 2010). Such actions of $\mathrm{D}_{2}$ dopamine receptors align with the notion that $\mathrm{D}_{2}$ receptor signaling is inhibitory and reduces the excitability of indirect-pathway MSNs. In addition, some studies have shown that $D_{2}$ receptor signaling reduces presynaptic glutamate release (Bamford et al. 2004; Yin and Lovinger 2006).

The widespread action of dopamine in the dorsal striatum affects interneurons as well. Dopamine can modulate local GABAergic neurons; FSIs can become excited by dopamine through $\mathrm{D}_{2}$ and $\mathrm{D}_{5}$ receptors. Studies have shown that $\mathrm{D}_{5}$ receptor activation depolarizes the membrane potential of FSIs (Bracci et al. 2002; Centonze et al. 2003). Also, $\mathrm{D}_{2}$ receptor agonists reduced presynaptic GABAergic neurotransmission in FSIs (Gage et al. 2010), which mostly originate from GPe neurons that express $\mathrm{D}_{2}$ receptors (Bevan et al. 1998; Hoover and Marshall 2004).

Cholinergic interneurons can be modulated by dopamine through $\mathrm{D}_{2}$ and $\mathrm{D}_{5}$ receptors. $\mathrm{D}_{2}$ receptor activation has been reported to suppress cholinergic autonomous firing activity by inhibiting voltage-dependent $\mathrm{Na}^{+}$channels (Maurice et al.
2004) or reducing hyperpolarization-activated depolarizing currents through HCN channels (Deng et al. 2007). $D_{2}$ receptors also mediate the inhibition of $\mathrm{Ca}_{\mathrm{v}} 2.2 \mathrm{Ca}^{2+}$ channels, ultimately reducing membrane excitability (Cabrera-Vera et al. 2004). Conversely, $D_{5}$ receptor activation depolarizes cholinergic interneurons through a cAMP-dependent pathway (Aosaki et al. 1998).

\section{Modulation of interneurons and MSNs by acetylcholine}

Acetylcholine (ACh) is another major neuromodulator supplied by large aspiny cholinergic interneurons that are tonically active $(<10 \mathrm{~Hz})$ in the striatum (Bolam et al. 1984). Although aspiny cholinergic interneurons constitute a small fraction of the total population, they also have a dense and widespread innervation of dendritic arbors in the striatum, contributing to a constituent background level of ACh as the acetylcholinesterase present in the extracellular matrix degrades the residual ACh.

Nicotinic ACh receptors ( $\mathrm{AAChR}$ ) expressed on presynaptic dopaminergic terminals can regulate dopamine release locally by initiating depolarization and calcium signaling to enhance dopamine release. ACh pulses arriving at dopaminergic terminals are degraded rapidly by acetylcholinesterase, thus minimizing the level of $\mathrm{nAChR}$ desensitization and allowing cholinergic activity to regulate dopaminergic axon terminals locally and release dopamine in an action-potential dependent manner (Zhou et al. 2001). In addition, recent studies have evaluated that the triggering force of dopamine release from axon terminals in the striatum by cholinergic interneurons is dominant over ascending dopaminergic somata firing (Cachope and Pereda 2012; Threlfell et al. 2012).

In addition, cholinergic interneurons may recruit distinctive sets of GABAergic circuits to modulate MSN output activity. ACh was shown to depolarize FSIs directly through nAChRs and attenuate their GABAergic inhibition on MSNs by presynaptic muscarinic acetylcholine receptors (mAChR) on FSI terminals (Koos and Tepper 2002). More recently, a study showed that activation of a novel inhibitory NPY-neurogliaform by nicotinic synaptic inputs from cholinergic interneurons contributes to slow inhibitory currents in MSNs (English et al. 2011).

In the case of MSNs, the principal neurons mainly express the muscarinic form of acetylcholine receptors, M1-like (M1 and M5) and M2-like (M2, M3, and M4) (Bernard et al. 1992). The M1-like receptors stimulate $\mathrm{G}_{\mathrm{q} / 11}$, which in turn activates phospholipase C (PLC) (Berstein et al. 1992) and protein kinase C (PKC) (Perez-Burgos et al. 2008), while M2-like receptors are coupled to $G_{i / o}$ proteins which inhibit adenylyl cyclase, thus reducing cAMP levels (McKinney et al. 1989) and inhibiting $\mathrm{Ca}^{2+}$ channels (Yan and Surmeier 1996). M1 receptors are highly enriched in both striatopallidal and striatonigral MSNs, and M4 receptors are expressed preferentially in striatonigral MSNs (Ince et al. 1997). M2 and M3 receptors are present in glutamatergic terminals of cortical projections (Ding et al. 2010).

M1 receptor activation on MSNs ultimately alters intrinsic excitability by modulating voltage-gated channels. Potassium currents through A-type $\mathrm{K}_{\mathrm{v}} 4$, Kir2, and KCNQ potassium channels are reduced by M1 receptor activation (Galarraga et al. 1999; Shen et al. 2005) and are accompanied by a shift in voltage-dependent activation and inactivation (Akins et al. 1990; Nakamura et al. 1997). Also, $\mathrm{M} 1$ negatively regulates $\mathrm{Ca}_{\mathrm{v}} 1.3$ channels by activating phospholipase $\mathrm{C}$ and protein phosphatase $2 \mathrm{~B}$ (PP-2B), and inhibits $\mathrm{Ca}_{\mathrm{v}} 2.1$ channels (Perez-Rosello et al. 2005; Perez-Burgos et al. 2010).

Cholinergic interneurons also express M2 and M4 receptors, which function as autoregulators. The activation of M2-class receptors results in a rapid reduction of $\mathrm{N}$ - and P-type $\mathrm{Ca}^{2+}$ currents 
through a membrane-delimited pathway that stimulates $\mathrm{G}_{\mathrm{i} / \mathrm{o}}$ proteins (Yan and Surmeier 1996).

\section{Striatal-based learning}

It has been clearly shown that the dorsal striatum can play a critical role in learning and memory. Early studies first suggested the involvement of striatum in instrumental conditioning and response-based learning (Divac et al. 1967). Later studies using excitotoxic lesions, drug-based approaches, or in vivo recording of neuronal activity have provided evidence that the dorsal striatum plays a role in skill learning and instrumental conditioning involving both goal-directed and habitual responding (Yin et al. 2005b, 2008; Yin and Knowlton 2006; Wickens et al. 2007; Grahn et al. 2008). Otherwise, it could be the striatum as a whole which is involved in most types of learning. However, until this point, very little is known about learning-induced plasticity in striatal microcircuits or how that memory is stored.

Goal-directed behavior during instrumental conditioning in rodents initiates with the association between a specific action and outcome and is prone to the degradation of action-outcome contingency or outcome revaluation (Balleine and Dickinson 1998). With extensive training, performance becomes habitual and no longer sensitive to degradation or devaluation (Dayan and Balleine 2002). This shift in learning is thought to be mediated by different subregions of the dorsal striatum; converging projections from the medial prefrontal cortex to the rodent dorsomedial striatum mediate the acquisition of goal-directed actions (Balleine and Dickinson 1998; Corbit and Balleine 2003; Balleine 2005; Yin et al. 2006), while projections from the sensorimotor cortex to the dorsolateral striatum mediate the acquisition of habits (Jog et al. 1999; Killcross and Coutureau 2003; Barnes et al. 2005). Consistent with results from lesion studies, direct injection of NMDAR antagonist into the dorsomedial striatum prevented goal-directed learning; in other words, the behavior was insensitive to devaluation (Yin et al. 2005a). In the dorsolateral striatum, on the other hand, excitotoxic lesions impaired habit learning (Yin et al. 2004; Hilario et al. 2007).

Receptors involved with striatal synaptic plasticity have been implied to be crucial for striatal-based learning. One study showed that CB1 receptor deletion impaired habit learning while actionoutcome learning remained intact (Hilario et al. 2007). This could indicate a role for endocannabinoids in habit learning and the possible involvement of CB1-mediated striatal LTD. Also, the role of $\mathrm{A}_{2 \mathrm{~A}}$ receptors seems important for promoting habit learning as $A_{2 A}$ receptor knockout mice were only able to show goaldirected behavior (Yu et al. 2009).

Given the fact that the neuronal population is heterogeneous, it is important to understand whether information is differently encoded by striatopallidal and striatonigral MSN pathways during instrumental conditioning. A study in the dorsomedial region using viral expression of channelrhodopsin-2 in $\mathrm{D}_{1^{-}}$and $\mathrm{D}_{2}$-Cre mouse lines somewhat illustrates this point (Kravitz et al. 2012). In an operant chamber, where mice were trained to receive light stimulation in response to a lever press, selective activation of striatonigral MSNs induced persistent reinforcement, whereas striatopallidal MSNs induced transient punishment.

This type of segregated encoding is observed during skill learning as well. Studies have shown that task-related firing during the early phase of skill learning develops in the dorsomedial region and gets more prominent in the dorsolateral as performance of the skill becomes automatized (Costa et al. 2004; Hernandez et al. 2006; Tang et al. 2007). A more recent study observed that these regional and training-specific changes were reflected as an enhanced excitatory synaptic transmission prefer- entially in the striatopallidal MSNs of the dorsolateral region (Yin et al. 2009).

\section{The modulation of excitatory and inhibitory balance in locomotion}

Concerted excitatory and inhibitory transmission activities in the CNS are essential for processing sensory information and cognitive function. Neuropsychiatric disorders such as autism, attention deficit/hyperactivity disorders (ADHD), and schizophrenia, and neurological disorders such as Parkinson's disease and epilepsy are often associated with an imbalance of excitatory and inhibitory neurotransmissions (Eichler and Meier 2008; Wang et al. 2010).

Dysfunction in the dorsal striatum, embedded with complex microcircuits galore, has been associated with neurological disorders, including Parkinson's disease, Huntington's disease, and psychiatric disorders such as obsessive-compulsive disorders (OCD) (Mink 2003; Welch et al. 2007). More recently, growing evidence has raised the possibility of striatal dysfunction associated with ADHD and autism (Durston et al. 2003; Lou et al. 2004; Di Martino et al. 2011; Peca et al. 2011). Interestingly, a notable number of mouse models for neuropsychiatric disorders share a common phenotype of elevated locomotor activity (Bolivar et al. 2004; Welch et al. 2007; Dzirasa et al. 2010; Penagarikano et al. 2011; Won et al. 2012). A study in mice deficient of contactin associated protein-like 2 (CNTNAP2) reported that hyperactivity and perseveration could be rescued by risperidone, a dopamine $\mathrm{D}_{2}$ receptor agonist, while social deficits remained impaired. This selective rescue clearly suggests a segregated pathway underlying motor dysfunction of psychiatric disorders (Penagarikano et al. 2011). Although an excitatory/inhibitory (E/I) balance has often been linked to explain psychiatrically disordered states, a direct examination of $\mathrm{E} / \mathrm{I}$ balance in the dorsal striatum under such states and its relevance to hyperactivity has not been attempted. Here we pool the results of recent studies and propose a functional role for the striatal microcircuits in motor impairment accompanied by neuropsychiatric disorders.

A balance of dopaminergic and cholinergic systems in the striatum has been suggested and studies have shown that an imbalance between these two systems can result in movement disorders in either hyperkinetic or hypokinetic aspects. For example, early observations of hyperactivity in the weaver mouse, a naturally occurring mutant mouse, reported a significant reduction of dopamine in the striatum (Schmidt et al. 1982). Interestingly, when dopamine receptor agonists were applied, hyperactivity was further increased, suggesting a supersensitization of dopamine receptors as a consequence of dopamine deficiency. In addition, mice deficient of $\mathrm{M} 1$ receptors exhibited both hyperactivity and elevated rearing activity, along with enhanced dopamine transmission in the striatum (Hamilton et al. 1997; Gerber et al. 2001). Recently, altered cholinergic control over dopamine release has been shown to directly result in hyperactivity in $\alpha 6^{\mathrm{L} 9^{\prime} \mathrm{S}}$ mice. Such mice have hypersensitive nicotinic $\alpha 6 \alpha 4 \beta 2^{*}$ channels that augment DA release from DA fibers during burst-firing in the dorsal striatum (Drenan et al. 2010). On the other hand, it has been reported that dopaminergic dysfunction and elevated cholinergic tone underlie hypokinetic movements of Parkinson's disease and several forms of dystonia (Augood et al. 2004; Clement et al. 2012). Thus, it seems that enhanced dopaminergic tone, stemming most likely from attenuated cholinergic signaling, results in hyperactivity. Given that the role for dopamine and acetylcholine is to alter membrane excitability of both principal neurons and interneurons in the striatum, it is important to understand how they alter E/I transmission in the dorsal striatum under psychiatrically disordered states. 


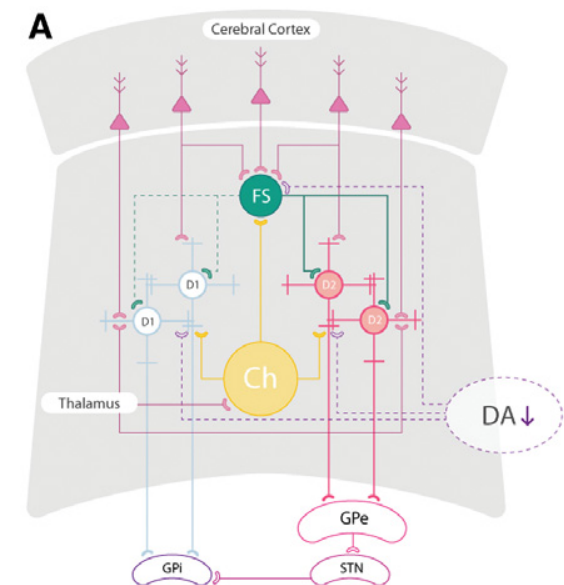

B

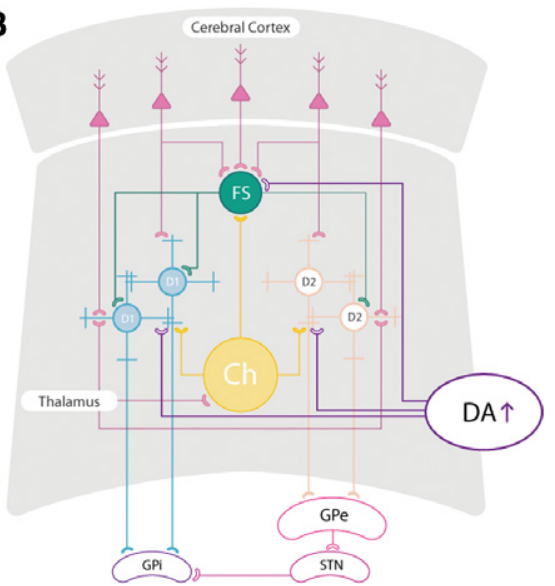

Figure 1. Imbalance of dopaminergic and cholinergic modulation can result in movement impairment. (A) Abnormal dopamine release and enhanced FSI activity may strengthen the output $\mathrm{D}_{1}$-MSN pathway and thus promote excessive locomotion. (B) Dopamine depletion triggers FSI circuit reorganization by reducing FSI connections to $D_{1}$-MSNs. In this case, the strength of the $\mathrm{D}_{2}$-MSN pathway may become more dominant than that of the $\mathrm{D}_{1}-\mathrm{MSN}$ pathway, resulting in reduced locomotion. (FS) fast-spiking interneuron, (Ch) cholinergic interneuron, (D1) $D_{1}-M S N$, (D2) $\mathrm{D}_{2}-\mathrm{MSN},(\mathrm{GPe})$ external globus pallidus, (GPi) internal globus pallidus, (STn) substantia nigra.

Cortical input to the dorsal striatum is the initial step and this is where FSIs seem to play an important role to mediate cortically driven striatal activity (Stern et al. 1998; Murer et al. 2002; Berke et al. 2004). In vivo gamma oscillations $(30-80 \mathrm{~Hz})$ in the striatum are confined to FSIs and coherent gamma oscillations between the cortex and striatum are suggested to be entrained through those connections in both anesthetized and awake states (Berke 2009; Sharott et al. 2009). Given that FSIs receive convergent input from the cortex and respond faster, allowing feed-forward inhibition on MSNs (Ramanathan et al. 2002; Mallet et al. 2005), it is most likely that the fast striatal oscillations will act in a broad coordinated manner to bring about rapid fluctuations of membrane potentials of MSNs that determine spiking during motor coordination (Plenz and Kitai 1998; Hasenstaub et al. 2005).

Differences in GABAergic transmission caused by a neuromodulatory network can have a strong influence over synaptic inputs to MSNs. More specifically, a loss of FSI-mediated control of MSN spike timing in pathophysiological states can result in impaired locomotion. In dopamine-depleted states, local field potential (LFP) recordings show a decreased power of gamma oscillation and an increased power of low-frequency oscillation in the dorsal striatum (Costa et al. 2006; Burkhardt et al. 2009). Given that dopamine increases FSI activity by depolarization (Bracci et al. 2002), such depletion could restrain FSIs from transition to up states where the power of high frequencies is enhanced (Schulz et al. 2011). In addition, dopamine depletion leads to HCN channelopathy in neurons of the external globus pallidus (GPe), which tend to fire in a synchronized fashion, while intrinsic autonomic firing is attenuated (Chan et al. 2011). Such synchronized neurons in the GPe project to FSIs (Bevan et al. 1998) and this could further impair gamma-frequency firing. Likewise, subsequent loss of dopamine dynamically remodels the microcircuits of FSIs by increasing synaptic contact with both striatonigral and striatopallidal MSNs (Salin et al. 2009; Gittis et al. 2011a). Thus, loss of dopamine may result in the broad range of hypolocomotion by reducing FSI activity and gamma oscillations, perhaps hindering directpathway MSNs from readily firing in response to cortical input. Consistent with this is a pharmacological study where selective inhibition of striatal FSIs led to dystonia in mice (Gittis et al. 2011b).
On the other hand, elevated dopaminergic tone in the dorsal striatum may almost do just the opposite. In vivo recordings of FSIs show that firing rates increase in response to amphetamine (a dopamine transporter blocker) and are positively correlated to enhanced locomotion (Wiltschko et al. 2010). In another pharmacological/ recording study, FSI firing activity positively correlates with drug-induced hyperlocomotion, caused by a combination of methamphetamine and endocannabinoid CB1 receptor antagonist, in the nucleus accumbens (Morra et al. 2010). Thus, dopamine may enhance the readiness of FSIs to fire in a coordinated manner with cortical input. In addition, gap junctions can determine firing rates of FSIs as well. It has been proposed that gap junctions reduce FSI firing rates by shunting when synaptic inputs are present (Hjorth et al. 2009) and studies in mice deficient of connexin31.1 observe hyperactivity (Dere et al. 2008). Given that GABAergic inhibition contributes differently to cortically evoked $\mathrm{D}_{1^{-}}$or $\mathrm{D}_{2^{-}}$MSN firing (FloresBarrera et al. 2010), it is possible that increased FSI activity could augment the length of a depolarized state in direct-pathway MSNs leading to excess locomotion (Fig. 1).

Alteration of glutamatergic transmission in the dorsal striatum by blockade of NMDARs may have a role in hyperactivity. Aberrant gamma oscillation throughout the mouse brain, including the dorsal striatum, is observed when psychotomimetics, such as ketamine or MK-801, are systemically applied (Hakami et al. 2009). Hyperactivity in striatal specific NR1 subunit deficient mice is correlated with a reduction of striatal gamma oscillation and, interestingly, hyperactivity can be reduced by either applying $\mathrm{D}_{1}$ or $\mathrm{D}_{2}$ receptor agonists (Ohtsuka et al. 2008). Such NMDAR hypofunction induced hyperactivity is thought to result from a reduced number of functional dopamine receptors (Ohtsuka et al. 2008). Examining the consequences of cell-type specific NMDAR hypofunction in the dorsal striatum might be needed to explain the state of hyperactivity.

Studying the excitatory and inhibitory balance in the dorsal striatum is likely to expand our understanding of motor dysfunction (specifically, hyperactivity) that accompanies neurological and psychiatric disorders. Perhaps additional examination of FSIs at the level of channels, such as voltage-gated sodium and potassium channels (Korotkova et al. 2010; Sciamanna and Wilson 2011; Verret et al. 2012), might better explain how membrane potentials of FSIs oscillate and alter under pathological states induced by an impaired balance of neuromodulators. Furthermore, manipulating specific cell types using mouse Cre-lines and optogenetic tools could provide a method for direct observation of hyperactivity.

\section{Acknowledgments}

This work was supported by the National Honor Scientist Program, WCU, and the National Creative Research Initiative Program, Korea. K.L. was supported by the Basic Science Research Program (2011-0028240) through the National Research Foundation of Korea. J.-I.K. was supported by a BK21 fellowship. 


\section{References}

Akins PT, Surmeier DJ, Kitai ST. 1990. Muscarinic modulation of a transient $\mathrm{K}+$ conductance in rat neostriatal neurons. Nature 344: 240-242.

Albin RL, Young AB, Penney JB. 1989. The functional anatomy of basal ganglia disorders. Trends Neurosci 12: 366-375.

Aosaki T, Kiuchi K, Kawaguchi Y. 1998. Dopamine D1-like receptor activation excites rat striatal large aspiny neurons in vitro. J Neurosci 18: 5180-5190.

Assisi C, Stopfer M, Laurent G, Bazhenov M. 2007. Adaptive regulation of sparseness by feedforward inhibition. Nat Neurosci 10: 1176-1184.

Atallah BV, Scanziani M. 2009. Instantaneous modulation of gamma oscillation frequency by balancing excitation with inhibition. Neuron 62: $566-577$.

Augood SJ, Hollingsworth Z, Albers DS, Yang L, Leung J, Breakefield XO, Standaert DG. 2004. Dopamine transmission in DYT1 dystonia. Adv Neurol 94: 53-60.

Balleine BW. 2005. Neural bases of food-seeking: Affect, arousal and reward in corticostriatolimbic circuits. Physiol Behav 86: 717-730.

Balleine BW, Dickinson A. 1998. Goal-directed instrumental action: Contingency and incentive learning and their cortical substrates. Neuropharmacology 37: 407-419.

Balleine BW, Delgado MR, Hikosaka O. 2007. The role of the dorsal striatum in reward and decision-making. J Neurosci 27: 8161-8165.

Bamford NS, Robinson S, Palmiter RD, Joyce JA, Moore C, Meshul CK. 2004 Dopamine modulates release from corticostriatal terminals. J Neurosci 24: $9541-9552$.

Barnes TD, Kubota Y, Hu D, Jin DZ, Graybiel AM. 2005. Activity of striatal neurons reflects dynamic encoding and recoding of procedural memories. Nature 437: 1158-1161.

Berke JD. 2009. Fast oscillations in cortical-striatal networks switch frequency following rewarding events and stimulant drugs. Eur J Neurosci 30: $848-859$.

Berke JD, Okatan M, Skurski J, Eichenbaum HB. 2004. Oscillatory entrainment of striatal neurons in freely moving rats. Neuron 43: 883-896.

Bernard V, Normand E, Bloch B. 1992. Phenotypical characterization of the rat striatal neurons expressing muscarinic receptor genes. J Neurosci 12 3591-3600.

Berstein G, Blank JL, Smrcka AV, Higashijima T, Sternweis PC, Exton JH, Ross EM. 1992. Reconstitution of agonist-stimulated phosphatidylinositol 4,5-bisphosphate hydrolysis using purified $\mathrm{m} 1$ muscarinic receptor, $\mathrm{Gq} / 11$, and phospholipase C-beta 1. J Biol Chem 267: 8081-8088.

Bevan MD, Booth PA, Eaton SA, Bolam JP. 1998. Selective innervation of neostriatal interneurons by a subclass of neuron in the globus pallidus of the rat. J Neurosci 18: 9438-9452.

Bolam JP, Wainer BH, Smith AD. 1984. Characterization of cholinergic neurons in the rat neostriatum. A combination of choline acetyltransferase immunocytochemistry, Golgi-impregnation and electron microscopy. Neuroscience 12: 711-718.

Bolam JP, Hanley JJ, Booth PA, Bevan MD. 2000. Synaptic organisation of the basal ganglia. J Anat 196(Pt 4): 527-542.

Bolivar VJ, Manley K, Messer A. 2004. Early exploratory behavior abnormalities in R6/1 Huntington's disease transgenic mice. Brain Res 1005: $29-35$.

Bracci E, Centonze D, Bernardi G, Calabresi P. 2002. Dopamine excites fast-spiking interneurons in the striatum. J Neurophysiol 87: 2190-2194.

Burkhardt JM, Jin X, Costa RM. 2009. Dissociable effects of dopamine on neuronal firing rate and synchrony in the dorsal striatum. Front Integr Neurosci 3: 28

Cabrera-Vera TM, Hernandez S, Earls LR, Medkova M, Sundgren-Andersson AK, Surmeier DJ, Hamm HE. 2004. RGS9-2 modulates D2 dopamine receptor-mediated $\mathrm{Ca}^{2+}$ channel inhibition in rat striatal cholinergic interneurons. Proc Natl Acad Sci 101: 16339-16344.

Cachope R, Pereda AE. 2012. Two independent forms of activity-dependent potentiation regulate electrical transmission at mixed synapses on the Mauthner cell. Brain Res 1487: 173-182.

Calabresi P, Maj R, Pisani A, Mercuri NB, Bernardi G. 1992a. Long-term synaptic depression in the striatum: Physiological and pharmacological characterization. J Neurosci 12: 4224-4233.

Calabresi P, Pisani A, Mercuri NB, Bernardi G. 1992b. Long-term potentiation in the striatum is unmasked by removing the voltage-dependent magnesium block of NMDA receptor channels. Eur J Neurosci 4: 929-935.

Centonze D, Picconi B, Gubellini P, Bernardi G, Calabresi P. 2001. Dopaminergic control of synaptic plasticity in the dorsal striatum. Eur J Neurosci 13: 1071-1077.

Centonze D, Grande C, Usiello A, Gubellini P, Erbs E, Martin AB, Pisani A, Tognazzi N, Bernardi G, Moratalla R, et al. 2003. Receptor subtypes involved in the presynaptic and postsynaptic actions of dopamine on striatal interneurons. J Neurosci 23: 6245-6254.

Chan CS, Glajch KE, Gertler TS, Guzman JN, Mercer JN, Lewis AS, Goldberg AB, Tkatch T, Shigemoto R, Fleming SM, et al. 2011. HCN channelopathy in external globus pallidus neurons in models of Parkinson's disease. Nat Neurosci 14: 85-92.

Chuhma N, Tanaka KF, Hen R, Rayport S. 2011. Functional connectome of the striatal medium spiny neuron. J Neurosci 31: 1183-1192.

Clement C, Lalonde R, Strazielle C. 2012. Acetylcholinesterase activity in the brain of dystonia musculorum (Dst(dt-J)) mutant mice. Neurosci Res 72: $79-86$.

Corbit LH, Balleine BW. 2003. The role of prelimbic cortex in instrumental conditioning. Behav Brain Res 146: $145-157$

Costa RM, Cohen D, Nicolelis MA. 2004. Differential corticostriatal plasticity during fast and slow motor skill learning in mice. Curr Biol 14: $1124-1134$

Costa RM, Lin SC, Sotnikova TD, Cyr M, Gainetdinov RR, Caron MG, Nicolelis MA. 2006. Rapid alterations in corticostriatal ensemble coordination during acute dopamine-dependent motor dysfunction. Neuron 52: 359-369.

Cowan WM, Powell TP. 1956. A study of thalamo-striate relations in the monkey. Brain 79: 364-390.

Dayan P, Balleine BW. 2002. Reward, motivation, and reinforcement learning. Neuron 36: 285-298.

Dehorter N, Guigoni C, Lopez C, Hirsch J, Eusebio A, Ben-Ari Y, Hammond C. 2009. Dopamine-deprived striatal GABAergic interneurons burst and generate repetitive gigantic IPSCs in medium spiny neurons. J Neurosci 29: 7776-7787.

DeLong MR. 1990. Primate models of movement disorders of basal ganglia origin. Trends Neurosci 13: 281-285.

Deng P, Zhang Y, Xu ZC. 2007. Involvement of I(h) in dopamine modulation of tonic firing in striatal cholinergic interneurons. I Neurosci 27: 3148-3156.

Dere E, Zheng-Fischhofer Q, Viggiano D, Gironi Carnevale UA, Ruocco LA, Zlomuzica A, Schnichels M, Willecke K, Huston JP, Sadile AG. 2008. Connexin31.1 deficiency in the mouse impairs object memory and modulates open-field exploration, acetylcholine esterase levels in the striatum, and cAMP response element-binding protein levels in the striatum and piriform cortex. Neuroscience 153: 396-405.

Di Martino A, Kelly C, Grzadzinski R, Zuo XN, Mennes M, Mairena MA, Lord C, Castellanos FX, Milham MP. 2011. Aberrant striatal functional connectivity in children with autism. Biol Psychiatry 69: 847-856.

Ding J, Peterson JD, Surmeier DJ. 2008. Corticostriatal and thalamostriatal synapses have distinctive properties. J Neurosci 28: 6483-6492.

Ding JB, Guzman JN, Peterson JD, Goldberg JA, Surmeier DJ. 2010. Thalamic gating of corticostriatal signaling by cholinergic interneurons. Neuron 67: 294-307.

Ding JB, Oh WJ, Sabatini BL, Gu C. 2012. Semaphorin 3E-Plexin-D1 signaling controls pathway-specific synapse formation in the striatum. Nat Neurosci 15: 215-223.

Divac I, Rosvold HE, Szwarcbart MK. 1967. Behavioral effects of selective ablation of the caudate nucleus. J Comp Physiol Psychol 63: 184-190.

Doig NM, Moss J, Bolam JP. 2010. Cortical and thalamic innervation of direct and indirect pathway medium-sized spiny neurons in mouse striatum. J Neurosci 30: 14610-14618.

Drenan RM, Grady SR, Steele AD, McKinney S, Patzlaff NE, McIntosh JM, Marks MJ, Miwa JM, Lester HA. 2010. Cholinergic modulation of locomotion and striatal dopamine release is mediated by $\alpha 6 \alpha 4^{*}$ nicotinic acetylcholine receptors. J Neurosci 30: 9877-9889.

Durston S, Tottenham NT, Thomas KM, Davidson MC, Eigsti IM, Yang Y, Ulug AM, Casey BJ. 2003. Differential patterns of striatal activation in young children with and without ADHD. Biol Psychiatry 53: $871-878$.

Dzirasa K, Coque L, Sidor MM, Kumar S, Dancy EA, Takahashi JS, McClung CA, Nicolelis MA. 2010. Lithium ameliorates nucleus accumbens phase-signaling dysfunction in a genetic mouse model of mania. J Neurosci 30: 16314-16323.

Eichler SA, Meier JC. 2008. E-I balance and human diseases - from molecules to networking. Front Mol Neurosci 1: 2. doi: 10.3389/ neuro.02.002.2008.

English DF, Ibanez-Sandoval O, Stark E, Tecuapetla F, Buzsaki G, Deisseroth K, Tepper JM, Koos T. 2011. GABAergic circuits mediate the reinforcement-related signals of striatal cholinergic interneurons. Nat Neurosci 15: 123-130.

Fino E, Glowinski J, Venance L. 2005. Bidirectional activity-dependent plasticity at corticostriatal synapses. J Neurosci 25: 11279-11287.

Flores-Barrera E, Vizcarra-Chacon BJ, Tapia D, Bargas J, Galarraga E. 2010 Different corticostriatal integration in spiny projection neurons from direct and indirect pathways. Front Syst Neurosci 4: 15. doi: 10.3389/ fnsys.2010.00015.

Flores-Hernandez J, Hernandez S, Snyder GL, Yan Z, Fienberg AA, Moss SJ, Greengard P, Surmeier DJ. 2000. D(1) dopamine receptor activation 
reduces $\mathrm{GABA}(\mathrm{A})$ receptor currents in neostriatal neurons through a PKA/DARPP-32/PP1 signaling cascade. J Neurophysiol 83: 2996-3004.

Gage GJ, Stoetzner CR, Wiltschko AB, Berke JD. 2010. Selective activation of striatal fast-spiking interneurons during choice execution. Neuron 67: 466-479.

Galarraga E, Hernandez-Lopez S, Reyes A, Miranda I, Bermudez-Rattoni F, Vilchis C, Bargas J. 1999. Cholinergic modulation of neostriatal output: A functional antagonism between different types of muscarinic receptors. J Neurosci 19: 3629-3638.

Galarraga E, Vilchis C, Tkatch T, Salgado H, Tecuapetla F, Perez-Rosello T, Perez-Garci E, Hernandez-Echeagaray E, Surmeier DJ, Bargas J. 2007. Somatostatinergic modulation of firing pattern and calcium-activated potassium currents in medium spiny neostriatal neurons. Neuroscience 146: $537-554$.

Gao T, Yatani A, Dell'Acqua ML, Sako H, Green SA, Dascal N, Scott JD, Hosey MM. 1997. cAMP-dependent regulation of cardiac L-type $\mathrm{Ca}^{2+}$ channels requires membrane targeting of PKA and phosphorylation of channel subunits. Neuron 19: 185-196.

Gerber DJ, Sotnikova TD, Gainetdinov RR, Huang SY, Caron MG, Tonegawa S. 2001. Hyperactivity, elevated dopaminergic transmission, and response to amphetamine in M1 muscarinic acetylcholine receptor-deficient mice. Proc Natl Acad Sci 98: 15312-15317.

Gerdeman GL, Ronesi J, Lovinger DM. 2002. Postsynaptic endocannabinoid release is critical to long-term depression in the striatum. Nat Neurosci 5: 446-451.

Gertler TS, Chan CS, Surmeier DJ. 2008. Dichotomous anatomical properties of adult striatal medium spiny neurons. J Neurosci 28: 10814-10824.

Gittis AH, Nelson AB, Thwin MT, Palop JJ, Kreitzer AC. 2010. Distinct roles of GABAergic interneurons in the regulation of striatal output pathways. J Neurosci 30: 2223-2234.

Gittis AH, Hang GB, LaDow ES, Shoenfeld LR, Atallah BV, Finkbeiner S, Kreitzer AC. 2011a. Rapid target-specific remodeling of fast-spiking inhibitory circuits after loss of dopamine. Neuron 71: $858-868$.

Gittis AH, Leventhal DK, Fensterheim BA, Pettibone JR, Berke JD, Kreitzer AC. 2011b. Selective inhibition of striatal fast-spiking interneurons causes dyskinesias. J Neurosci 31: 15727-15731.

Gong S, Zheng C, Doughty ML, Losos K, Didkovsky N, Schambra UB, Nowak NJ, Joyner A, Leblanc G, Hatten ME, et al. 2003. A gene expression atlas of the central nervous system based on bacterial artificial chromosomes. Nature 425: 917-925.

Grahn JA, Parkinson JA, Owen AM. 2008. The cognitive functions of the caudate nucleus. Prog Neurobiol 86: 141-155.

Greif GJ, Lin YJ, Liu JC, Freedman JE. 1995. Dopamine-modulated potassium channels on rat striatal neurons: Specific activation and cellular expression. J Neurosci 15: 4533-4544.

Hakami T, Jones NC, Tolmacheva EA, Gaudias J, Chaumont J, Salzberg M, O'Brien TJ, Pinault D. 2009. NMDA receptor hypofunction leads to generalized and persistent aberrant gamma oscillations independent of hyperlocomotion and the state of consciousness. PloS One 4: e6755. doi: 10.1371 /journal.pone.0006755.

Hamilton SE, Loose MD, Qi M, Levey AI, Hille B, McKnight GS, Idzerda RL, Nathanson NM. 1997. Disruption of the $\mathrm{m} 1$ receptor gene ablates muscarinic receptor-dependent $\mathrm{M}$ current regulation and seizure activity in mice. Proc Natl Acad Sci 94: 13311-13316.

Hasenstaub A, Shu Y, Haider B, Kraushaar U, Duque A, McCormick DA. 2005. Inhibitory postsynaptic potentials carry synchronized frequency information in active cortical networks. Neuron 47: 423-435.

Hernandez PJ, Schiltz CA, Kelley AE. 2006. Dynamic shifts in corticostriatal expression patterns of the immediate early genes Homer 1a and Zif268 during early and late phases of instrumental training. Learn Mem 13: 599-608.

Hernandez-Lopez S, Bargas J, Surmeier DJ, Reyes A, Galarraga E. 1997. D1 receptor activation enhances evoked discharge in neostriatal medium spiny neurons by modulating an L-type $\mathrm{Ca}^{2+}$ conductance. J Neurosci 17: $3334-3342$.

Hernandez-Lopez S, Tkatch T, Perez-Garci E, Galarraga E, Bargas J, Hamm H, Surmeier DJ. 2000. D2 dopamine receptors in striatal medium spiny neurons reduce L-type $\mathrm{Ca}^{2+}$ currents and excitability via

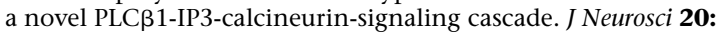
8987-8995.

Higley MJ, Sabatini BL. 2010. Competitive regulation of synaptic $\mathrm{Ca}^{2+}$ influx by D2 dopamine and A2A adenosine receptors. Nat Neurosci 13: 958-966.

Hilario MR, Clouse E, Yin HH, Costa RM. 2007. Endocannabinoid signaling is critical for habit formation. Front Integr Neurosci 1: v6. doi: $10.3389 /$ neuro.07.006.2007.

Hjorth J, Blackwell KT, Kotaleski JH. 2009. Gap junctions between striatal fast-spiking interneurons regulate spiking activity and synchronization as a function of cortical activity. J Neurosci 29: 5276-5286.

Hoover BR, Marshall JF. 2004. Molecular, chemical, and anatomical characterization of globus pallidus dopamine D2 receptor mRNA-containing neurons. Synapse 52: 100-113.
Ince E, Ciliax BJ, Levey AI. 1997. Differential expression of D1 and D2 dopamine and $\mathrm{m} 4$ muscarinic acetylcholine receptor proteins in identified striatonigral neurons. Synapse 27: 357-366.

Jog MS, Kubota Y, Connolly CI, Hillegaart V, Graybiel AM. 1999. Building neural representations of habits. Science 286: 1745-1749.

Kato S, Kuramochi M, Kobayashi K, Fukabori R, Okada K, Uchigashima M, Watanabe M, Tsutsui Y. 2011. Selective neural pathway targeting reveals key roles of thalamostriatal projection in the control of visual discrimination. J Neurosci 31: 17169-17179.

Kawaguchi Y. 1993. Physiological, morphological, and histochemical characterization of three classes of interneurons in rat neostriatum. J Neurosci 13: 4908-4923.

Killcross S, Coutureau E. 2003. Coordination of actions and habits in the medial prefrontal cortex of rats. Cereb Cortex 13: 400-408.

Kitai ST, Surmeier DJ. 1993. Cholinergic and dopaminergic modulation of potassium conductances in neostriatal neurons. Adv Neurol 60: 40-52.

Koos T, Tepper JM. 1999. Inhibitory control of neostriatal projection neurons by GABAergic interneurons. Nat Neurosci 2: 467-472.

Koos T, Tepper JM. 2002. Dual cholinergic control of fast-spiking interneurons in the neostriatum. J Neurosci 22: 529-535.

Korotkova T, Fuchs EC, Ponomarenko A, von Engelhardt J, Monyer H. 2010. NMDA receptor ablation on parvalbumin-positive interneurons impairs hippocampal synchrony, spatial representations, and working memory. Neuron 68: 557-569.

Kravitz AV, Tye LD, Kreitzer AC. 2012. Distinct roles for direct and indirect pathway striatal neurons in reinforcement. Nat Neurosci 15: 816-818.

Kreitzer AC, Malenka RC. 2007. Endocannabinoid-mediated rescue of striatal LTD and motor deficits in Parkinson's disease models. Nature 445: $643-647$.

Kubota Y, Kawaguchi Y. 2000. Dependence of GABAergic synaptic areas on the interneuron type and target size. I Neurosci 20: 375-386.

Levy LM, Hallett M. 2002. Impaired brain GABA in focal dystonia. Ann Neurol 51: $93-101$.

Lou HC, Rosa P, Pryds O, Karrebaek H, Lunding J, Cumming P, Gjedde A. 2004. ADHD: Increased dopamine receptor availability linked to attention deficit and low neonatal cerebral blood flow. Dev Med Child Neurol 46: $179-183$.

Lovinger DM. 2010. Neurotransmitter roles in synaptic modulation, plasticity and learning in the dorsal striatum. Neuropharmacology 58: 951-961.

Mallet N, Le Moine C, Charpier S, Gonon F. 2005. Feedforward inhibition of projection neurons by fast-spiking GABA interneurons in the rat striatum in vivo. J Neurosci 25: 3857-3869.

Maurice N, Mercer J, Chan CS, Hernandez-Lopez S, Held J, Tkatch T, Surmeier DJ. 2004. D2 dopamine receptor-mediated modulation of voltage-dependent $\mathrm{Na}^{+}$channels reduces autonomous activity in striatal cholinergic interneurons. J Neurosci 24: 10289-10301.

McCairn KW, Bronfeld M, Belelovsky K, Bar-Gad I. 2009. The neurophysiological correlates of motor tics following focal striatal disinhibition. Brain 132: 2125-2138.

McKinney M, Anderson D, Vella-Rountree L. 1989. Different agonist-receptor active conformations for rat brain M1 and M2 muscarinic receptors that are separately coupled to two biochemical effector systems. Mol Pharmacol 35: 39-47.

Mink JW. 2003. The basal ganglia and involuntary movements: Impaired inhibition of competing motor patterns. Arch Neurol 60: $1365-1368$.

Morra JT, Glick SD, Cheer JF. 2010. Neural encoding of psychomotor activation in the nucleus accumbens core, but not the shell, requires cannabinoid receptor signaling. J Neurosci 30: 5102-5107.

Murer MG, Tseng KY, Kasanetz F, Belluscio M, Riquelme LA. 2002. Brain oscillations, medium spiny neurons, and dopamine. Cell Mol Neurobiol 22: $611-632$

Nakamura TY, Coetzee WA, Vega-Saenz De Miera E, Artman M, Rudy B. 1997. Modulation of $\mathrm{K}_{\mathrm{v}} 4$ channels, key components of rat ventricular transient outward $\mathrm{K}^{+}$current, by PKC. Am J Physiol 273: $\mathrm{H} 1775-\mathrm{H} 1786$.

Neve KA, Seamans JK, Trantham-Davidson H. 2004. Dopamine receptor signaling. J Recept Signal Transduct Res 24: 165-205.

O’Donnell P, Grace AA. 1997. Cortical afferents modulate striatal gap junction permeability via nitric oxide. Neuroscience 76: 1-5.

Ohtsuka N, Tansky MF, Kuang H, Kourrich S, Thomas MJ, Rubenstein JL, Ekker M, Leeman SE, Tsien JZ. 2008. Functional disturbances in the striatum by region-specific ablation of NMDA receptors. Proc Natl Acad Sci 105: $12961-12966$.

Okada F, Crow TJ, Roberts GW. 1990. G-proteins $\left(\mathrm{G}_{\mathrm{i}}, \mathrm{G}_{\mathrm{o}}\right)$ in the basal ganglia of control and schizophrenic brain. J Neural Transm Gen Sect 79: $227-234$

Pawlak V, Kerr JN. 2008. Dopamine receptor activation is required for corticostriatal spike-timing-dependent plasticity. J Neurosci 28: $2435-2446$. 
Peca J, Feliciano C, Ting JT, Wang W, Wells MF, Venkatraman TN, Lascola CD, Fu Z, Feng G. 2011. Shank3 mutant mice display autistic-like behaviours and striatal dysfunction. Nature 472: 437-442.

Penagarikano O, Abrahams BS, Herman EI, Winden KD, Gdalyahu A, Dong H, Sonnenblick LI, Gruver R, Almajano J, Bragin A, et al. 2011. Absence of CNTNAP2 leads to epilepsy, neuronal migration abnormalities, and core autism-related deficits. Cell 147: 235-246.

Perez-Burgos A, Perez-Rosello T, Salgado H, Flores-Barrera E, Prieto GA, Figueroa A, Galarraga E, Bargas J. 2008. Muscarinic M(1) modulation of $\mathrm{N}$ and $\mathrm{L}$ types of calcium channels is mediated by protein kinase $\mathrm{C}$ in neostriatal neurons. Neuroscience 155: 1079-1097.

Perez-Burgos A, Prieto GA, Galarraga E, Bargas J. 2010. $\mathrm{Ca}_{\mathrm{V}} 2.1$ channels are modulated by muscarinic M1 receptors through phosphoinositide hydrolysis in neostriatal neurons. Neuroscience 165: 293-299.

Perez-Rosello T, Figueroa A, Salgado H, Vilchis C, Tecuapetla F, Guzman JN, Galarraga E, Bargas J. 2005. Cholinergic control of firing pattern and neurotransmission in rat neostriatal projection neurons: Role of $\mathrm{Ca}_{\mathrm{V}} 2.1$ and $\mathrm{Ca}_{\mathrm{V}} 2.2 \mathrm{Ca}^{2+}$ channels. J Neurophysiol 93: 2507-2519.

Planert H, Szydlowski SN, Hjorth JJ, Grillner S, Silberberg G. 2010. Dynamics of synaptic transmission between fast-spiking interneurons and striatal projection neurons of the direct and indirect pathways. $J$ Neurosci 30: 3499-3507.

Plenz D, Kitai ST. 1998. Up and down states in striatal medium spiny neurons simultaneously recorded with spontaneous activity in fast-spiking interneurons studied in cortex-striatum-substantia nigra organotypic cultures. J Neurosci 18: 266-283.

Ramanathan S, Hanley JJ, Deniau JM, Bolam JP. 2002. Synaptic convergence of motor and somatosensory cortical afferents onto GABAergic interneurons in the rat striatum. J Neurosci 22: 8158-8169.

Salin P, Lopez IP, Kachidian P, Barroso-Chinea P, Rico AJ, Gomez-Bautista V, Coulon P, Kerkerian-Le Goff L, Lanciego JL. 2009. Changes to interneuron-driven striatal microcircuits in a rat model of Parkinson's disease. Neurobiol Dis 34: 545-552.

Schiffmann SN, Desdouits F, Menu R, Greengard P, Vincent JD, Vanderhaeghen JJ, Girault JA. 1998. Modulation of the voltage-gated sodium current in rat striatal neurons by DARPP-32, an inhibitor of protein phosphatase. Eur J Neurosci 10: 1312-1320.

Schmidt MJ, Sawyer BD, Perry KW, Fuller RW, Foreman MM, Ghetti B. 1982. Dopamine deficiency in the weaver mutant mouse. J Neurosci 2: 376-380.

Schulz JM, Pitcher TL, Savanthrapadian S, Wickens JR, Oswald MJ, Reynolds JN. 2011. Enhanced high-frequency membrane potential fluctuations control spike output in striatal fast-spiking interneurones in vivo. J Physiol 589: 4365-4381.

Sciamanna G, Wilson CJ. 2011. The ionic mechanism of gamma resonance in rat striatal fast-spiking neurons. J Neurophysiol 106: 2936-2949.

Sharott A, Moll CK, Engler G, Denker M, Grun S, Engel AK. 2009. Different subtypes of striatal neurons are selectively modulated by cortical oscillations. J Neurosci 29: 4571-4585.

Shen W, Hamilton SE, Nathanson NM, Surmeier DJ. 2005. Cholinergic suppression of KCNQ channel currents enhances excitability of striatal medium spiny neurons. J Neurosci 25: 7449-7458.

Smeal RM, Gaspar RC, Keefe KA, Wilcox KS. 2007. A rat brain slice preparation for characterizing both thalamostriatal and corticostriatal afferents. J Neurosci Methods 159: 224-235.

Smith Y, Bevan MD, Shink E, Bolam JP. 1998. Microcircuitry of the direct and indirect pathways of the basal ganglia. Neuroscience 86: 353-387.

Stern EA, Jaeger D, Wilson CJ. 1998. Membrane potential synchrony of simultaneously recorded striatal spiny neurons in vivo. Nature 394: $475-478$.

Stoof JC, Kebabian JW. 1984. Two dopamine receptors: Biochemistry, physiology and pharmacology. Life Sci 35: 2281-2296.

Tanda K, Nishi A, Matsuo N, Nakanishi K, Yamasaki N, Sugimoto T, Toyama K, Takao K, Miyakawa T. 2009. Abnormal social behavior, hyperactivity, impaired remote spatial memory, and increased D1-mediated dopaminergic signaling in neuronal nitric oxide synthase knockout mice. Mol Brain 2: 19. doi: 10.1186/1756-6606-2-19.

Tang C, Pawlak AP, Prokopenko V, West MO. 2007. Changes in activity of the striatum during formation of a motor habit. Eur J Neurosci 25: 1212-1227.

Threlfell S, Lalic T, Platt NJ, Jennings KA, Deisseroth K, Cragg SJ. 2012. Striatal dopamine release is triggered by synchronized activity in cholinergic interneurons. Neuron 75: 58-64.

Verret L, Mann EO, Hang GB, Barth AM, Cobos I, Ho K, Devidze N, Masliah E, Kreitzer AC, Mody I, et al. 2012. Inhibitory interneuron deficit links altered network activity and cognitive dysfunction in Alzheimer model. Cell 149: 708-721.

Vida I, Bartos M, Jonas P. 2006. Shunting inhibition improves robustness of gamma oscillations in hippocampal interneuron networks by homogenizing firing rates. Neuron 49: 107-117.

Vilchis C, Bargas J, Ayala GX, Galvan E, Galarraga E. 2000. $\mathrm{Ca}^{2+}$ channels that activate $\mathrm{Ca}^{2+}$-dependent $\mathrm{K}^{+}$currents in neostriatal neurons. Neuroscience 95: 745-752.

Wang Z, Kai L, Day M, Ronesi J, Yin HH, Ding J, Tkatch T, Lovinger DM, Surmeier DJ. 2006. Dopaminergic control of corticostriatal long-term synaptic depression in medium spiny neurons is mediated by cholinergic interneurons. Neuron 50: 443-452.

Wang M, Pei L, Fletcher PJ, Kapur S, Seeman P, Liu F. 2010. Schizophrenia, amphetamine-induced sensitized state and acute amphetamine exposure all show a common alteration: Increased dopamine D2 receptor dimerization. Mol Brain 3: 25. doi: 10.1186/1756-6606-3-25.

Welch JM, Lu J, Rodriguiz RM, Trotta NC, Peca J, Ding JD, Feliciano C, Chen M, Adams JP, Luo J, et al. 2007. Cortico-striatal synaptic defects and OCD-like behaviours in Sapap3-mutant mice. Nature 448: 894-900.

West AR, Grace AA. 2004. The nitric oxide-guanylyl cyclase signaling pathway modulates membrane activity states and electrophysiological properties of striatal medium spiny neurons recorded in vivo. J Neurosci 24: $1924-1935$.

Wickens JR, Horvitz JC, Costa RM, Killcross S. 2007. Dopaminergic mechanisms in actions and habits. J Neurosci 27: 8181-8183.

Wiltschko AB, Pettibone JR, Berke JD. 2010. Opposite effects of stimulant and antipsychotic drugs on striatal fast-spiking interneurons. Neuropsychopharmacology 35: 1261-1270.

Won H, Lee HR, Gee HY, Mah W, Kim JI, Lee J, Ha S, Chung C, Jung ES, Cho YS, et al. 2012. Autistic-like social behaviour in Shank2-mutant mice improved by restoring NMDA receptor function. Nature $\mathbf{4 8 6}$ : 261-265.

Worbe Y, Baup N, Grabli D, Chaigneau M, Mounayar S, McCairn K, Feger J, Tremblay L. 2009. Behavioral and movement disorders induced by local inhibitory dysfunction in primate striatum. Cereb Cortex 19: $1844-1856$.

Yan Z, Surmeier DJ. 1996. Muscarinic $(\mathrm{m} 2 / \mathrm{m} 4)$ receptors reduce N- and P-type $\mathrm{Ca}^{2+}$ currents in rat neostriatal cholinergic interneurons through a fast, membrane-delimited, G-protein pathway. J Neurosci 16: $2592-2604$

Yin HH, Knowlton BJ. 2006. The role of the basal ganglia in habit formation. Nat Rev Neurosci 7: 464-476.

Yin HH, Lovinger DM. 2006. Frequency-specific and D2 receptor-mediated inhibition of glutamate release by retrograde endocannabinoid signaling. Proc Natl Acad Sci 103: 8251-8256.

Yin HH, Knowlton BJ, Balleine BW. 2004. Lesions of dorsolateral striatum preserve outcome expectancy but disrupt habit formation in instrumental learning. Eur J Neurosci 19: 181-189.

Yin HH, Knowlton BJ, Balleine BW. 2005a. Blockade of NMDA receptors in the dorsomedial striatum prevents action-outcome learning in instrumental conditioning. Eur J Neurosci 22: 505-512.

Yin HH, Ostlund SB, Knowlton BJ, Balleine BW. 2005b. The role of the dorsomedial striatum in instrumental conditioning. Eur J Neurosci 22 513-523.

Yin HH, Knowlton BJ, Balleine BW. 2006. Inactivation of dorsolateral striatum enhances sensitivity to changes in the action-outcome contingency in instrumental conditioning. Behav Brain Res 166: 189-196.

Yin HH, Ostlund SB, Balleine BW. 2008. Reward-guided learning beyond dopamine in the nucleus accumbens: The integrative functions of cortico-basal ganglia networks. Eur J Neurosci 28: 1437-1448.

Yin HH, Mulcare SP, Hilario MR, Clouse E, Holloway T, Davis MI, Hansson AC, Lovinger DM, Costa RM. 2009. Dynamic reorganization of striatal circuits during the acquisition and consolidation of a skill. Nat Neurosci 12: 333-341.

Yu C, Gupta J, Chen JF, Yin HH. 2009. Genetic deletion of A2A adenosine receptors in the striatum selectively impairs habit formation. J Neurosci 29: $15100-15103$.

Zhou FM, Liang Y, Dani JA. 2001. Endogenous nicotinic cholinergic activity regulates dopamine release in the striatum. Nat Neurosci 4: 1224-1229.

Received April 6, 2012; accepted in revised form October 29, 2012. 


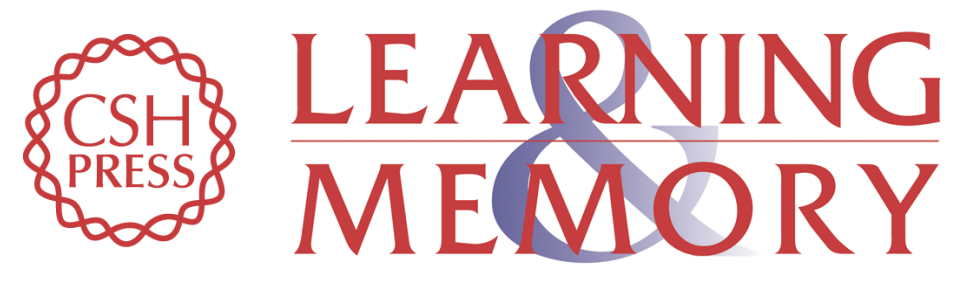

\section{Functional roles of neurotransmitters and neuromodulators in the dorsal striatum}

Jeehaeh Do, Jae-Ick Kim, Joseph Bakes, et al.

Learn. Mem. 2013, 20:

Access the most recent version at doi:10.1101//m.025015.111

References This article cites 148 articles, 50 of which can be accessed free at: http://learnmem.cshlp.org/content/20/1/21.full.html\#ref-list-1

License Freely available online through the Learning \& Memory Open Access option.

Email Alerting Receive free email alerts when new articles cite this article - sign up in the box at the Service top right corner of the article or click here. 